\title{
Influencing Factors Of Business-Fraud Intention On Young Muslim Entrepreneurs In Palembang City
}

\author{
Febrianty ${ }^{\mathrm{I}}$ Divianto ${ }^{2}$ \\ Polytechnic of PalComTech ${ }^{1}$, State Polytechnic of Sriwijaya ${ }^{2}$ \\ febrianty@palcomtech.ac.id ${ }^{1}$, divi.kardin@gmail.com²
}

\begin{abstract}
The purpose of this study was to determine the factors that affect the intention of business-fraud on young entrepreneurs in Palembang city. Researchers conducted research development on young-Muslim entrepreneurs as subjects and added the role stress variable and applied TPB Theory. The type of data used in the form of primary data through questionnaires. The analysis of this research used SEMAnalysis. The results of this study were: HI-predicted a positive correlation between attitudes and intention of young-Muslim entrepreneurs to commit business-fraud (accepted). $\mathrm{H}-2$ and $\mathrm{H}-3$ there was rejection because there were more influential variables. H4-predicted there was a positive correlation between the role-stress and intention of young-Muslim entrepreneurs to commit business-fraud (accepted). H5predicted that attitudes toward behavior, subjective-norms, and perceived-behavioral controls have significant influence on the intention of young Muslim entrepreneurs to commit business-fraud. Potential business young-Muslim entrepreneurs can fraud occur in the business, needs to be improved by effectiveness of internal controls.
\end{abstract}

Keywords: Intention, Business-Fraud, young-Muslim, attitudes, role-stress, subjective-norms, perceived-behavioral controls, TPB

\section{A. INTRODUCTION}

Fraud is an act that causes potential harm to other people, companies, organizations, employees, or other parties. Fraud can occur in various fields, whether committed by employees or management. Fraud committed by employees is called Employee Fraud while Fraud conducted by management is called Management Fraud. Examples of well-known accounting and business fraud cases are: Enron's case, he manipulates financial statements to make the company's performance look better. Enron marks the revenue up and keeps the debt confidential. Another case is the fall in stock prices of Worldcom. The fall in Worldcom's stock price is due to the fact that in its financial statements the company recognized the network expense as capital expenditure. Enron has practiced a window dressing. Enron's management has marked its revenue up of $\$$ 
600 million and hide its debt as many as US \$ I.2 billion. This kind of practice can only be done by people who have expertise with high manipulation tricks and of course these people are paid people such as financial analysts, legal advisors, and auditors (Said, 2002). Another real case, about mid-April 2009, BPOM (Food and Drug Supervisory Agency) finds five brands of beef jerky and beef floss that positively contained pigs, to reduce the cost of production (nahimunkar.com).

According to the Association of Certified Fraud Examiners (ACFE) based in the United States, which is an association whose members are the testers of fraud action, fraud is a cheating action which is conducted in various ways in a cunning and deceptive manner and it is often not realized by disadvantaged victims. Fraud can be divided into three major parts: Asset Misappropriation, Fraudulent Financial Statement, and Corruption. However, fraud is not limited to the above, other things included in the fraud are hiding certain documents/reports, falsify documents for business interests, disfiguring other company's products, breach of the contract, or distribute confidential company information to outside parties without the knowledge of the authorities and provide false information related to products/services produced by the business, provide public lies, and so forth. Various other forms of fraud which has not been included in the above classification. ACFE also states in the Report to the Nations on Occupational Fraud and Abuse reports that cases of fraud and abuse that occurred in 2016 reached 24 IO fraud in the workplace that occurred in II4 countries around the world.

Some previous studies provided inconsistent results regarding the implementation of Theory of Planned Behavior. Prior research one of them conducted by (Uddin \& Gillett, 2002) stated that subjective norms have a negative effect on financial managers' intentions in fraudulent of financial statements presentation. The result of different research is stated by (Carpenter \& Reimers, 2005) which provided empirical evidence that subjective norms had a positive effect on financial managers' intentions in fraudulent of financial statement presentation. In addition, previous research is also more emphasis in fraudulent the presentation of financial statements. Other research conducted by (Anggelina \& Edwin, 2014) stated that attitudes, subjective norms, and behavior control simultaneously and partially affect customers which would be purchased at the SOGO Department Store at Tunjungan Plaza Surabaya, and behavioral control was compared with attitudes and subjective norms.

This study extends fraud studies in business fraud intentions. With the subject of Young Muslim Entrepreneurs in Palembang City with the growing 
number of entrepreneurs in Palembang City is increasing. According to (Dubrin, 1982) entrepreneur is a person who established and runs an innovative business.

Young age, high confidence, and productive, and likes challenges, create very high enthusiasm and courage of young entrepreneurs in improving profit and develop their business. Sometimes, it also causes young entrepreneurs to commit business fraudulent acts that they realize or do not realize. Though one of the keys to becoming a successful entrepreneur is honesty both to yourself, others, and goals to be achieved. Honesty is a moral foundation that is sometimes forgotten by an entrepreneur amid the business competition and the achievement of profit targets even if the profit achieved exceeds the target.

According to (Zimmerer \& Scarborough., 2002), the success and failure of entrepreneurship is highly dependent on personal ability. The success of entrepreneurship is to have a clear vision and purpose, willing to take money and time risks, planned and organized, hard work according to importance, develop good relationships with customers, suppliers and employees. While the failure according to (Zimmerer \& Scarborough., 2002), the following causes are incompetent in managerial, inexperienced, lack of financial control, failure in planning, inadequate location, lack of equipment supervision, lack of seriousness in the effort, inability to make transition.

Islamic history also notes that Prophet Muhammad SAW, his wife and most of his companions were entrepreneurs. Muslim entrepreneurship emphasizes the entrepreneurial concept of a Muslim who have a solid foundation that has been largely ignored or less enlarged by Muslims themselves, although today Indonesia is the country with the largest Islamic adherents in the world. The strong foundation of Muslim entrepreneurship in the teachings of Islam can not only be explored and developed from the contextual understanding of Al-Qur'an but also derived from its textual meaning. If Islam is studied in depth it turns out to be the religion that supports entrepreneurship in the world.

Islam knows the word Syari'ah or Islamic Laws that regulate about worship and muamalah. Syari' ah has a strong foundation in the form of human wisdom and happiness for life in the world and the Hereafter. Etymologically, Syari'ah means a straight path or a path that leads to a flowing spring that wants to be drunk (Mujibatun, 2012). Shaykh al-Qardhawi defined the word Syariah has a fairly broad and comprehensive understanding. It contains an understanding of worship aspects, muamalah, economy, and family. Syariah business is a polite business, a business which is full of togetherness and respect for the rights of both sellers and buyers (Kartajaya \& Sula, 20I3). 
Syafi'i Antonio, Syariah has its own uniqueness, sharia is not only comprehensive, but also universal. Universal means that Syariah can be applied anytime and anywhere by every human being. The universality is primarily in the social (economic) field that makes no distinction between Muslims and nonMuslims (Kartajaya \& Sula, 2013). To answer these questions Allah has revealed the Holy Qur'an as a guide for Muslims. Based on the definition, Syari'ah-based business is a business activity undertaken by a person based on Islamic Syariah, every way of obtaining and using the property they get must be in accordance with the rules of Islam (Halal and Haram). In Islamic business, someone must always remember and submit all the effort results that has been done to Allah, by submitting to Allah and consider working as a worship, someone will always be sincere in working, this is called as Tauhid al-Uluhiyyah. Therefore, being a Muslim entrepreneur should refer to Islamic business ethics that originates in the Qur'an as a guide. Al-Qur'an is the source of all teachings for all Muslims which explain about norms, rules or laws, and the values that govern all human activities including in business activities (Arifin, 2009). Researchers conduct research development on young Muslim entrepreneur subjects and add role stress variable. Job stress can occur, one of which is influenced by age because elder age is assumed to have more experience than the relatively younger age. The renewal of this research is that researchers try to connect the complexity of the business problems faced by Young Muslim Entrepreneurs who are seen through stress role associated with the possibility of committing business fraud intentions.

The purpose of this study is to determine factors that affect the intention of business fraud on young entrepreneurs in the Palembang city.

\section{B. THEORITICAL}

\section{Islamic Perspective on Entrepreneurship}

In the perspective of Islam, a Muslim is strongly advised to make efforts to seek sustenance/income. In a verse of the Qur'an in Surah Al-Jumu'ah, verse I0, it says "And when the prayer is ended, then disperse on the earth and seek of Allah's bounty, and remember Allah much, that you may be successful."(Depag, 2013). Based on the translation of the Qur'an verse, it clearly shows that the God commands human to make earnest efforts by calling on humans to "disperse" on the earth to seek the grace of God that has been bestowed on this earth. Most Muslims throughout the earth still respond casually or less seriously to the word "disperse ", in the verse above. The proof is no one to do a very deep study on the "word of God's command". So far, in various Islamic literature have never been 
found studies which take seriously the matter of "denial" of Muslims or neglect the God's call or command. Yet if Muslims in a kaffah or thorough consistently run the call of God, certainly, from the first when this verse is revealed until now, the banner of Islam will continue flying as a leader for the welfare of mankind throughout this universe.

\section{Theory of Planned Behavior (TPB)}

$\mathrm{TPB}$ is the development of Reasoned Action Theory (Fishbein \& Ajzen, I975; Ajzen \& Fishbein, I980 cited by (Ajzen, I99I) which is made due to the limitations of the model at the beginning to deal with the behavior in which people do not have volitional control. As in TRA, the central factor of TPB is the individual's intention to perform certain behavior. This study uses TPB which is found by (Ajzen, I99I), it states that the main factor of a person's behavior is the individual's intention on the behavior. Intention to conduct a behavior is influenced by three variables, namely: attitudes, subjective norms, and perceived behavioral control. The stronger the intention to be involved in a behavior, the greater the possibility of performance (Ajzen, I99I).

TPB postulated three determinants of the intention on a conceptually standalone basis. The first is an attitude toward behavior that refers to the extent to which a person has a supportive or non-supportive evaluation or judgment of the behavior (Ajzen, I99I). Attitudes toward behavior are the overall evaluation of a person's behavior (Ajzen, 2002). The second predictor is a social factor which is known as the subjective norm that refers to the perceived social pressure to perform or not to engage in behavior. The third antecedent is a perceived level of behavior control that refers to perceptions of ease or difficulty in performing behavior and is assumed to reflect past experiences and the anticipation of obstacles (Ajzen, I99I). Generally, the more supportive attitudes and subjective norms and the greater the control of perceived behavior, the stronger the intention of a person to perform the behavior. All predictors in TPB can be assessed directly by asking respondents to rate each predictor according to a series of scales. In addition, attitudes toward behavior, subjective norms, and perceived behavior control can be measured indirectly, based on appropriate beliefs (Ajzen, 2002).

\section{Cognitive Dissonance Theory}

Cognitive Dissonance Theory was developed by Leon Festinger in 1957. This theory stated that human basically like consistency, therefore human will tend to take attitudes that do not contradict each other and avoid doing actions that are 
not in accordance with the attitude. Dissonance means an inconsistency. Cognitive dissonance means the unpleasant psychological state that arises when there is a conflict between two cognitions or conflict between behavior and attitude. In this theory the meaning of the cognitive element is any knowledge, opinion, or what someone believes about object, environment, oneself, or behavior. Cognitive dissonance can occur in relevant or related cognitive elements (Festinger, 1957, in (Azwar, 1998).

\section{Fraud}

Fraud is an activity that occurs in a social environment and it has serious consequences on economics, companies, and individuals. The Association of Certified Fraud Examiners (ACFE) classifies fraud into three schemes called the fraud tree, namely corruption, misuse of assets, and financial statements fraud. The results indicate that the perpetrators of fraud have a lifestyle that is higher than the income or salary received. Satisfied or dissatisfied with salary has an influence in cheating. According to (Tang \& Chiu, 2003) individuals who have satisfaction with their salary tend not to commit fraud.

According to (Hall, 20II), Fraud is a misstatement of material facts which is made by one party to another party with the intention to deceive and cause other parties who rely on that fact will lose. Generally, fraud activity includes the following five conditions: I. False Representation, there must be an errorneous or incomplete presentation in the statements, 2. Material Fact, fact is substantial thing that drive person to do something, 3 . Intent, there is always an intention to deceive, 4. Justifiable Reliance, misstatement of substantial factor that is relied by the loss party, 5. Injury or Loss, the fraud which is conducted resulted in a loss to the victim.

Fraud Triangle is an example of a model that encourages individuals to commit fraud (Cressey, I953). The model illustrates three main factors of fraud: motivation, opportunity, and rationalization. In motivational term, there is "nonshareable problem" which means situations where the problems of the individual can not be informed to others. This creates a strong motivation to defraud. After having the motivation and availability of opportunity, fraud can be used as a solution to the problems (Prabowo, 20I4). The emerging opportunities are linked to the weakness of the organization's control system with a low probability of knowing. This opportunity can only be done by people who have the ability to do it without detected (Wolfe \& Hermanson, 2004). Fraud comes with a rationalization to justify the behavior. Rationalization is needed so that the 
perpetrator can accept the unlawful behavior to keep the identity as a trusted person. Opinion of rationalization has various types such as "I deserve it", "management does not care about me", "no one is hurt", "this is to help the company" (Prabowo, 2014).

\section{Correlation between Attitudes and Intention of Fraud}

According to (Kanuk, 2008) attitude is the tendency to act that resulted from learning outcome with consistent purpose, which shows the likes or unlikes of an object. Whereas according to (Kotler \& Amstrong, 2008) attitude is evaluation, feeling, and tendency of individual to object that relatively consistent. Attitudes put person in thinking framework about to like or unlike, get closer or instead avoid something. Generally, individual who believes attitudes can bring postive results has positive attitudes on behavior and vice versa (Ajzen, 2005).

The correlation between attitudes toward behavior in intention is based on the theory of planned behavior which was developed by Ajzen (I975). (Ajzen \& Fishbein, 1975) in their article "Understanding Attitudes and Predicting Social Behavior" stated that the main determining factor is personality. How an individual evaluates whether a behavior is positive or negative before doing the action. Salient belief is the powerful factor to correlate attitudes in order to achive valuable results whether positive or negative. According to the description, it can be expressed the first hypothesis as follows:

HI: Attitudes toward behavior positively influence the intention of young muslim entrepreneurs to commit business fraud.

\section{Correlation between Subjective Norms and Intention of Fraud}

According to (Ajzen, 2007), subjective norm is how far person has motivation to follow others' perspective on what behavior should done (normative belief). If a person feels what is done as individual right, so the person literally ignores others' perspective about what behavior should done.

The correlation between subjective norms and intention of fraud based on theory of planned behavior which was developed by (Ajzen, I99I). Subjective norm is the factor from outside of individual that shows someone's perception on the behavior. (Ajzen, I99I) defined subjective norms as pressure on someone to do or not to do the behavior. (Bobek \& R. C. Hatfield, 2003) stated that subjective norm refers to someone's belief which individuals/groups will accept or reject someone's behavior.(Kreitner \& Kinicki., 2005) stated that subjective norms can strongly influence, purpose of individual's behavior that sensitive on how people's 
opinions will affect behavior that should be done or not. Subjective norm is perception or perespective on someone's belief that will affect interest to do or not do behavior that still on consideration (Hartono, 2007). Research of (Carpenter \& Reimers, 2005) proved that subjective norms positively influence on manager's intention to deceive. Therefore, the second hypothesis is as follows:

H2: Subjective norms positively influence the intention of young muslim entrepreneurs to commit business fraud.

\section{Correlation between Perceived Behavioral Control and Intention of Fraud}

(Ajzen, 2007) states that perceived behavioral control which is felt is also the function of control belief and access to the control factor. The internal control factors are: skill, ability, information, dan emotion. Meanwhile the external control factors are: situation and environment. Perceived behavioral control which is felt indicates that motivation of individual is affected by perception on how difficult certain behavior can be done, how far the possible success that will be achieved by the individual if doing certain berhaviors. Generally, individual think rather rationally and able to use the information which they have, so if the individual does not have any resources or chances to do something, then the individual will not do the behavior. (eventhough in the situation where individual has attitudes and subjective norms that accepted the behavior).

The correlation between perceived behavioral control is based on theory of planned behavior. (Ajzen, I99I) in the article with the title, The Theory of Planned Behavior. "Organizational Behavior and Human Decision Processes", he states that perceived behavioral control shows on individual perception toward ease or difficulty to show the intended behavior. Theory of Ajzen (1988) states that the bigger someone has chances as well as obstacles that can be anticipated, the bigger someone has perceived control on the behavior. The same thing stated from research results of (Hays, 2005) that perceived behavioral control has strong correlation with the intention to do whistleblowing. So perceived behavioral control is resulted from an indvidual's perception to the behavior that he will do, where someone feels confident if the perception he has is the result of control of himself about perception on the behavior. According to the description, it can be expressed the third hypothesis is as follows:

H3: Perceived behavioral control positively influences the intention of young muslim entrepreneurs to commit business fraud. 


\section{Correlation between Role Stress and Intention of Fraud}

Theory of role stress emphasizes individual nature as social actor who learns the behavior which is suitable with his position in community (Katz \& Kahn, 1978). One source of stress encountered by most individuals in working is role stress which is defined as role conflict and role ambiguity (Kahn, Wolfe, Quinn, \& Snoek., 1964). Role stress that is experienced can be correlated to lower job satisfaction, increased job-related tension, propensity to leave the organization, (Rebele \& Michaels, 1990). According to (Senatra, 1980), potention of role conflict and role ambiguity not only affects the individual in emotional consequence such as high tense job and low job satisfaction but also for the business with low quality performance and higher turnover. According to the description, it can be expressed the fourth hypothesis is as follows:

$\mathrm{H} 4$ : Role stress positively influence the intention of young muslim entrepreneurs to commit business fraud.

\section{Research Hypotheses}

$\mathrm{H}_{\mathrm{I}}=$ Attitudes toward business fraud behavior positively and significantly influence the intention of young muslim entrepreneurs to commit business fraud.

$\mathrm{H}_{2}=$ Subjective norms toward business fraud behavior positively and significantly influence the intention of young muslim entrepreneurs to commit business fraud

$\mathrm{H}_{3}=$ Perceived behavioral control toward business fraud behavior positively and significantly influence the intention of young muslim entrepreneurs to commit business fraud

$\mathrm{H}_{3}=$ Role Stress positively and significantly influence the intention of young muslim entrepreneurs to commit business fraud

$\mathrm{H}_{5}=$ Attitudes toward behavior, subjective norms, and perceived behavioral control as well as role stress toward business fraud behavior positively and significantly influence the intention of young muslim entrepreneurs to commit business fraud 
Influencing Factors Of Business-Fraud Intention On Young Muslim Entrepreneurs

In Palembang City

Febrianty $^{1}$, Divianto ${ }^{2}$

\section{Research Framework}

The research framework can be seen on Figure I.

Figure I.

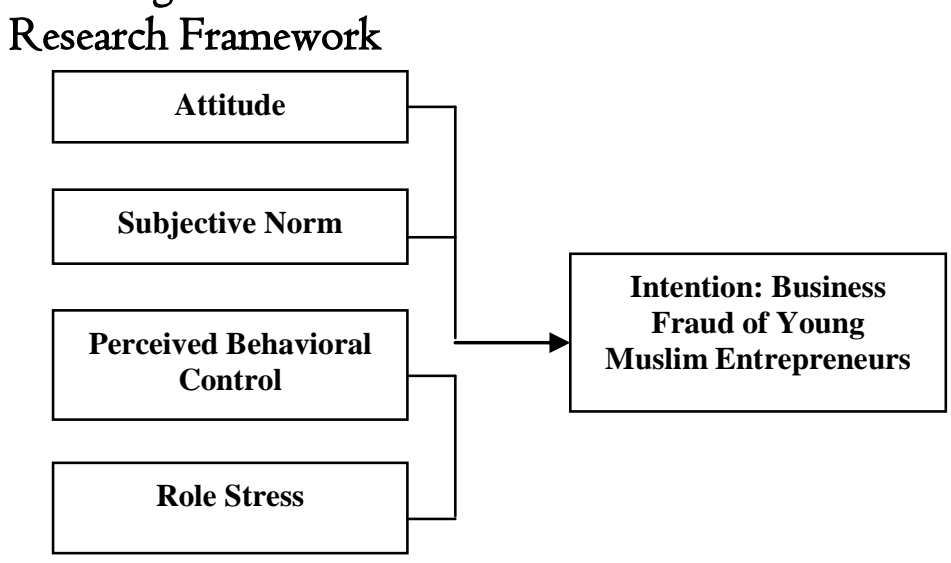

\section{METHODOLOGY}

\section{Sampling}

In this study, the population was a young Muslim entrepreneurs in Palembang who has been recorded in two trainings organized by the Creative Economy Agency (Bekraf) of Palembang City. The method which is used in this research is purposive sampling. Young Muslim entrepreneurs were aged between I8-25 years old, business owners, and still in school or college. The number of samples obtained based on criteria which can be processed as many as I29 young Muslims entrepreneurs.

\section{Data Collection}

The design of this research is causal explanatory. Subjects in the research were young muslim entrepreneurs. Research conducted in 2016. Independent variables which is tested is attitudes toward behaviors, subjective norms and perceived behavioral control. Dependent variables, namely intention and behavior of business fraud. This study used qualitative data which is a list of questionnaire statements about the variables: attitudes toward behaviors, subjective norms, perceived behavioral control, role stress, intention of business fraud. The source of the data came from the respondent's answer to the statements contained in the research questionnaire. 
IKONOMIKA

Volume 4, No I (2019)

\section{Table I \\ Research Indicators}

\begin{tabular}{|c|c|c|c|}
\hline No & Variable & Definition & Indicator \\
\hline $\mathrm{I}$ & Attitude & $\begin{array}{l}\text { Attitudes toward behaviors refer } \\
\text { to how far a person has an } \\
\text { evaluation that supports or does } \\
\text { not support or assess the } \\
\text { behavior (Ajzen, I99I). } \\
\text { Attitudes toward behavior in this } \\
\text { study refer to the degree which a } \\
\text { person will provide a favorable } \\
\text { assessment or does not commit a } \\
\text { business fraud. }\end{array}$ & $\begin{array}{l}\text { - Interest with the lure of profits to be } \\
\text { gained/trust in the profits of business } \\
\text { fraud, } \\
\text { - Views on business failure, } \\
\text { - Unpreparedness to deal with business } \\
\text { risks that will occur/diffidence } \\
\text { - Inability to evaluate how important it is } \\
\text { to do business fraud (evaluation of } \\
\text { important) } \\
\text { - Uncertainty in assessing the risk of } \\
\text { business fraud }\end{array}$ \\
\hline 2 & $\begin{array}{l}\text { Subjective } \\
\text { Norm }\end{array}$ & $\begin{array}{l}\text { Subjective norms refer to the } \\
\text { perceived social pressure to } \\
\text { behave or not (Ajzen, I99I). } \\
\text { The subjective norms in this } \\
\text { study refer to the perceived } \\
\text { social pressure to commit or not } \\
\text { to commit business fraud. }\end{array}$ & $\begin{array}{l}\text { - Pressure from family, } \\
\text { - Pressure from people who are } \\
\text { considered important, } \\
\text { - Pressure from business competitors } \\
\text { - Pressure from the creditor/investor } \\
\text { - Pressure from consumers/potential } \\
\text { customers }\end{array}$ \\
\hline 3 & $\begin{array}{l}\text { Perceived } \\
\text { Behavioral } \\
\text { Control }\end{array}$ & $\begin{array}{l}\text { Perceived behavioral control } \\
\text { refers to the perception of ease } \\
\text { or difficulty in performing } \\
\text { behaviors and is assumed to } \\
\text { reflect past experiences as well as } \\
\text { the anticipation of obstacles } \\
\text { (Ajzen, I99I). The perceived } \\
\text { behavioral control is the } \\
\text { perception of ease or difficulty } \\
\text { in committing business fraud. }\end{array}$ & $\begin{array}{l}\text { - Power possessed if doing business fraud } \\
\text { (perceived power) } \\
\text { - Confidence in the ability to control } \\
\text { (control belief) }\end{array}$ \\
\hline 4 & $\begin{array}{l}\text { Role } \\
\text { Stress }\end{array}$ & $\begin{array}{l}\text { Situations which place } \\
\text { individuals to have moral or } \\
\text { immoral behaviors and their } \\
\text { relation to others (Senatra, } \\
\text { I980) }\end{array}$ & $\begin{array}{l}\text { - Role conflict } \\
\text { - Role ambiguity }\end{array}$ \\
\hline 5 & $\begin{array}{l}\text { Intention } \\
\text { of } \\
\text { Business } \\
\text { Fraud }\end{array}$ & $\begin{array}{l}\text { The intention of business fraud } \\
\text { is assumed to capture } \\
\text { motivational factors that } \\
\text { influence fraudulent behavior. } \\
\text { The business fraud intention } \\
\text { indicates an attempt that the }\end{array}$ & $\begin{array}{l}\text { - Choosing to commit business fraud as a } \\
\text { form of solution in a pressing situation } \\
\text { - Choosing to commit business fraud as a } \\
\text { way to earn more and more profits } \\
\text { - Choosing to commit business fraud as a } \\
\text { form of sustaining business continuity }\end{array}$ \\
\hline
\end{tabular}

https://ejournal.radenintan.ac.id/index.php/ikonomika

E-mail:ikonomika_submission@radenintan.ac.id 
Influencing Factors Of Business-Fraud Intention On Young Muslim Entrepreneurs

In Palembang City

Febrianty $^{1}$, Divianto ${ }^{2}$

person will commit business

fraud behavior (Prabowo, 20I4)

\section{Measurement}

The structural equations, can be built on the following guidelines:

Endogenous Variables = Exogenous Variables + Endogenous Variables + Error The analysis of this research used Structural Equation Modeling (SEM) Analysis which is operated through Lisrel Program. One of the objectives of path analysis is to determine whether the model is plausible/fit or not. A research model will be good if it has a good fit model as well. According to Hulland et al quoted in (Ferdinand, A., 2005), several conformity indexes and their "cut-off value" are used to test whether a model is accepted or rejected, namely:

\section{Table 2.}

Goodness of Fit Index

\begin{tabular}{l|l}
\hline Goodness of Fit Index & Cut-of Value \\
\hline$\chi 2$-Chi-square & Expected to be small \\
Significancy Probability & $\geq 0.05$ \\
RMSEA & $\leq 0.08$ \\
GFI & $0-$ I \\
AGFI & $\geq 0.90$ \\
CMIN/DF & $\geq 3.00$ \\
TLI & $\geq 0.95$ \\
CFI & $0-1$ \\
\hline
\end{tabular}

Source: Ferdinand (2005)

\section{RESULTS AND DISCUSSION}

\section{RESULTS}

Research Data Description

Details of distribution and questionnaires return are presented in Table 3.

\section{Table 3}

Details of distribution and return of questionnaires

\begin{tabular}{lc}
\hline \multicolumn{1}{c}{ Information } & $\begin{array}{c}\text { Number of } \\
\text { Questionnaries }\end{array}$ \\
\hline Distributed Questionnaries & I34 \\
Returned Questionnaries & I3I \\
Unreturned Questionnaries & 3
\end{tabular}


Incomplete Questionnaries

Processed Questionnaries

Usable Response rate (I29/I34 x I00\%) 96.27\%

Source: processed research data

Based on the data in Table 3. the number of questionnaires processed is I29 which means the level of usable rate response remains high enough that is equal to 96.27\%. The descriptions of respondents in number and percentage, by sex, age, business duration, education, and type of business, are described in Table 4.

Table 4.

Statistic Variable Description

\begin{tabular}{|c|c|c|}
\hline Information & Total & Percentage \\
\hline \multicolumn{3}{|l|}{ Sex } \\
\hline Female & 53 & 41.09 \\
\hline Male & 76 & $58.9 \mathrm{I}$ \\
\hline Total & 129 & $\mathrm{I00}$ \\
\hline \multicolumn{3}{|l|}{ Age } \\
\hline I8-I9 years old & I I & 8.53 \\
\hline 20-2I years old & 21 & 16.28 \\
\hline $22-23$ years old & 35 & 27.13 \\
\hline $24-25$ years old & 62 & $48 / 06$ \\
\hline Total & 129 & I00 \\
\hline \multicolumn{3}{|l|}{ Business duration } \\
\hline Less than one year-one year & 28 & $2 \mathrm{I} .7 \mathrm{I}$ \\
\hline Between $2-3$ years & IOI & 78.29 \\
\hline & $\mathrm{I} 29$ & $\mathrm{IO0}$ \\
\hline \multicolumn{3}{|l|}{ Education Level } \\
\hline Still highschool & I7 & I3.I8 \\
\hline Still D3/SI & II 2 & 86.82 \\
\hline Total & 129 & I00 \\
\hline \multicolumn{3}{|l|}{ Type of Business } \\
\hline Craft & 27 & 20.93 \\
\hline Food and beverages & 24 & 18.60 \\
\hline Publishing and printing & 25 & 19.38 \\
\hline Computer and software service & II & 8.53 \\
\hline Advertising, video, and & 19 & $\mathrm{I} 4.73$ \\
\hline
\end{tabular}


Influencing Factors Of Business-Fraud Intention On Young Muslim Entrepreneurs

In Palembang City

Febrianty $^{1}$, Divianto ${ }^{2}$

$\begin{array}{lcc}\text { photography } & 2 \mathrm{I} & \mathrm{I} 6.28 \\ \text { Fashion } & 2 & \mathrm{I} .55\end{array}$

Art goods

$\begin{array}{lll}\text { Total } & \text { I29 } & \text { I00 }\end{array}$

Source: processed primary data

Based on Table 4. Sample respondents from young Muslim entrepreneurs in this study are male dominant, aged between 24-25 years old, business duration between 2-3 years, dominant education level is enrolled in D3/SI program, and dominant business group is from crafting.

\section{Confirmatory Factor Analysis (Cfa) Test}

\section{a). Exogenous Construct CFA}

Exogenous Construct CFA Model can be seen in Figure 2. (see Figure 2.).

Figure 2

Model_I Exogenous Construct CFA

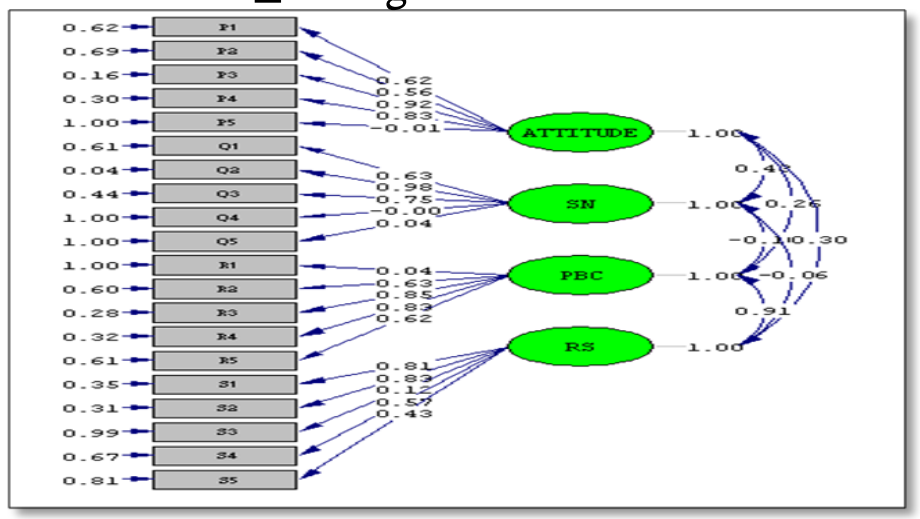

Based on Figure I., it can be seen that Model_I Exogenous Construct CFA still have a loading factor value less than 0.5, that is P5 indicator on ATTITUDE variable, Indicators $\mathrm{Q} 4$ and $\mathrm{Q} 5$ on SUBJECTIVE NORM (SN) variable, RI indicator on PERCEIVED BEHAVIORAL CONTROL (PBC) variable, S3 and S5 Indicator on ROLE STRESS (RS) variable. The indicators have not been valid and must be issued in subsequent analysis so that the Model_2 Exogenous construct CFA is as follows. 
IKONOMIKA

Volume 4, No I (2019)

\section{Figure 3}

\section{Model_2 Exogenous Construct CFA}

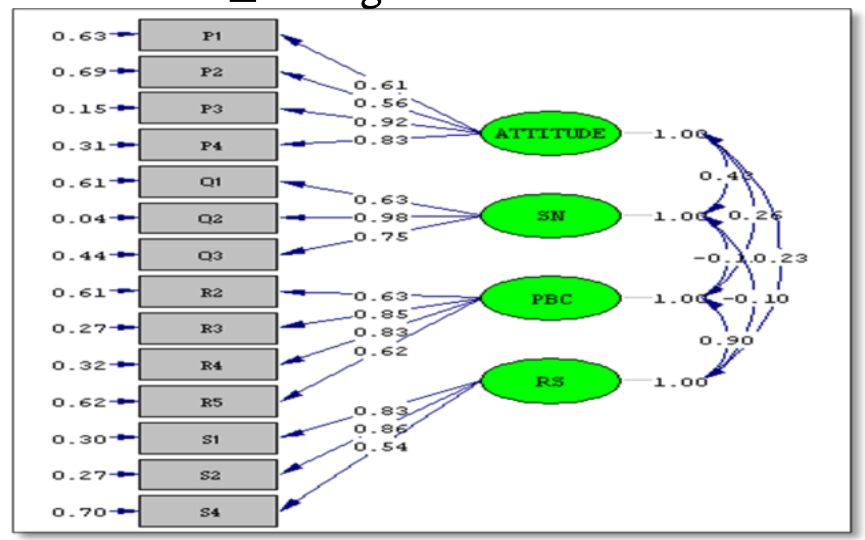

Based on Figure 3 it indicates that Model_2 Exogenous Construct CFA does not have loading factor value less than 0.5, so all the indicators on the Exogenous variable have been shown to be valid. The results of reliability calculations with Construct Reliability/ CR of exogenous variable Confirmatory Factor Analysis/CFA can be seen in Table 2.

\section{b). Endogenous Construct CFA}

Endogenous construct confirmatory factor analysis can be seen in Figure 4.

\section{Figure 4}
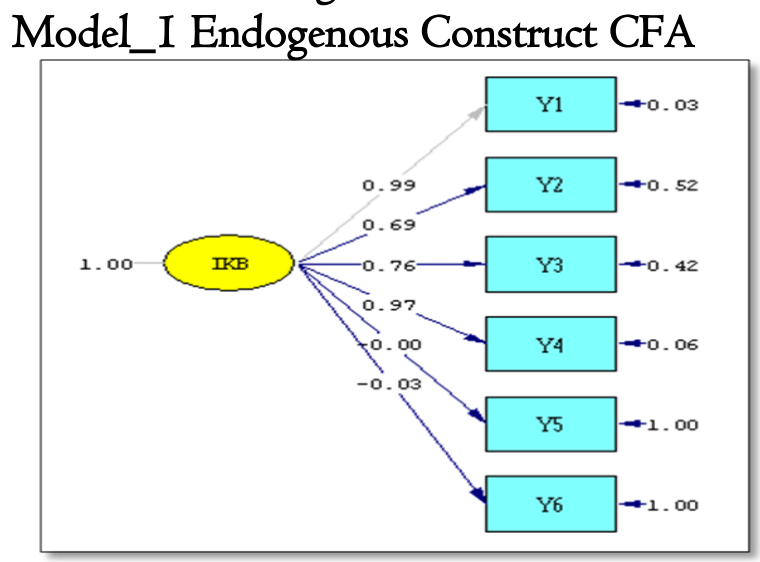

Based on Figure 4., it can be seen that Model_I CFA Endogenous Construct have a loading factor value less than 0.5 , namely Y5 and Y 6 on the INTENTION OF BUSINESS FRAUD (IKB) variable, meaning that the indicators have not been valid and must be issued in subsequent analysis so that obtain the endogenous construct Model_2 CFA as follows. 
IKONOMIKA: Jurnal Ekonomi dan Bisnis Islam

Volume 4, No. I (2019)

ISSN : 2527-3434 (PRINT) - ISSN: 2527-5I43 (ONLINE)

Page : 85 - I08

Based on Figure 4 it indicates that Model_2 Endogenous Construct CFA does not have loading factor value less than 0.5 , so the indicator on the endogenous variable has been shown to be valid. The results of reliability calculations with Construct Reliability/ CR of endogenous variable Confirmatory Factor Analysis/CFA can be seen in Table 2.

\section{Table 5}

Validity and Reliability Test Results of Endogenous Construct Variable

\begin{tabular}{c|c|c|c|c}
\hline Dimension & Indicator & $\boldsymbol{\lambda}$ & $\begin{array}{c}\text { Error }=\mathrm{I}- \\
\boldsymbol{\lambda}^{2}\end{array}$ & $\begin{array}{c}\mathrm{CR}=\left(\sum \lambda\right)^{2} /\left((\Sigma \lambda)^{2}\right. \\
\left.+\sum \text { Error }\right)\end{array}$ \\
\hline INTENTI & Y I & 0.99 & 0.02 & \\
ON OF & Y2 & 0.69 & 0.52 & 0.919 \\
BUSINESS & Y3 & 0.76 & 0.42 & \\
FRAUD & Y4 & 0.97 & 0.06 & \\
(IKB) & & &
\end{tabular}

Based on Figure 4. and Table 5. the Model_2 Endogenous Construct CFA has no loading factor value less than 0.5 , so the indicator on the endogenous variable has been shown to be valid. While the $\mathrm{CR}$ value indicates that of all exogenous constructs above 0.7 . Thus, it can be concluded that all dimensions and research variables have good reliability.

\section{Structural Equation Modelling (SEM) Analysis}

Based on SEM analysis, presented Goodness of Fit Index as follows.

\section{Figure 5 .}

\section{Estimation Result of Full Model Based on t-value}

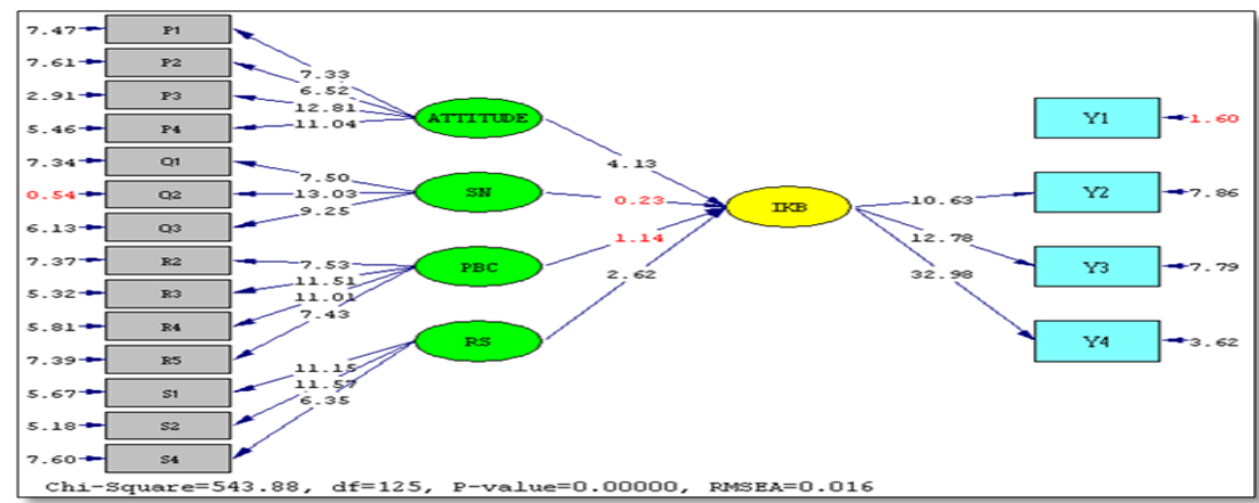

Submitted : March 6, 2019 - Revised: May 25, 2019 - Accepted :June 20, 2019

Polytechnic of PalComTech ${ }^{1}$, State Polytechnic of Sriwijaya ${ }^{2}$

E-Mail: febrianty@,palcomtech.ac.id',divi.kardin@gmail.com 
The estimation results of full model SEM analysis based on t-value are shown in the following Figure 5. Based on Figure 5. it can be seen two parameters in the Full Model which do not have significant effect on IKB (t-value is smaller than I.96), namely $\mathrm{SN}$ and $\mathrm{PBC}$ variables. There are two significant variables affecting IKB namely ATTITUDE and RS variables at the $0.05 \%$ level. The estimation results for full model SEM analysis based on loading standard are shown in the following Figure 6 and Table 6.

Figure 6.

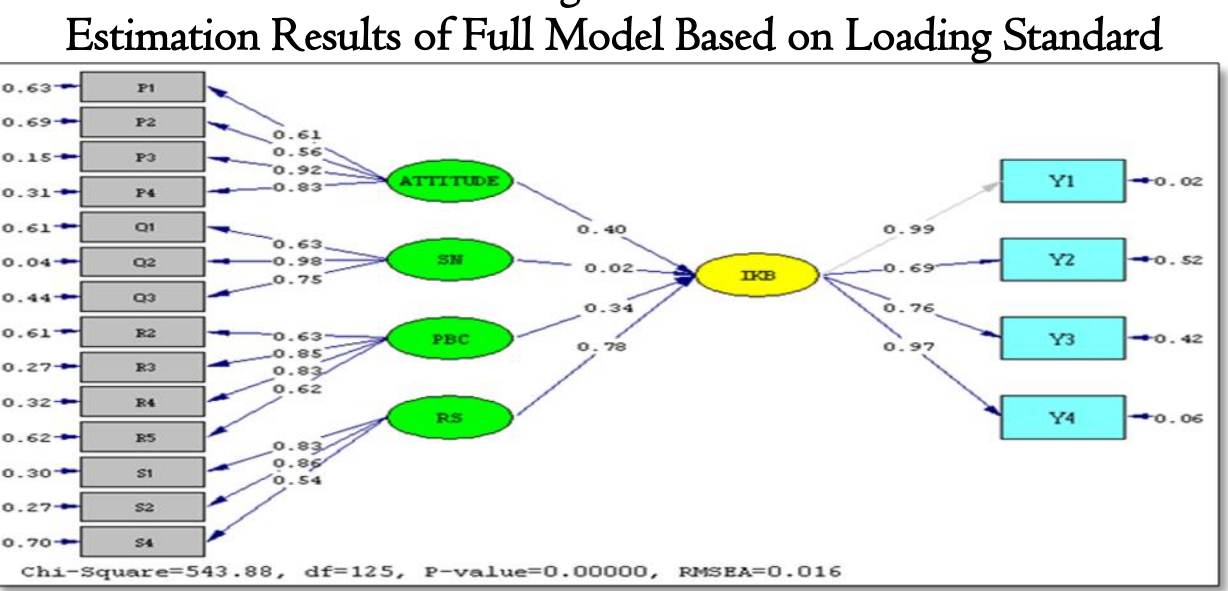

Table 6.

Goodness of Fit Index

\begin{tabular}{l|l|r|l}
\hline No & $\begin{array}{l}\text { Goodness of Fit } \\
\text { Index }\end{array}$ & Value & Information \\
\hline I. & Chi-Square & 543.88 & Marginal Fit \\
& Probability & 0.000 & \\
2. & RMSEA & 0.016 & Good Fit \\
3. & NFI & 0.96 & Good Fit \\
4. & NNFI & 0.94 & Good Fit \\
5. & CFI & 0.97 & Good Fit \\
6. & IFI & 0.97 & Good Fit \\
7. & RMR & 0.05 & Good Fit \\
8. & GFI & 0.88 & Marginal Fit \\
9. & AGFI & 0,86 & Marginal Fit \\
\hline
\end{tabular}

Structural Equation:

$\mathrm{IKB}=0.40^{*} \mathrm{ATTITUDE}+0.020^{*} \mathrm{SN}+0.34^{*} \mathrm{PBC}+0.78^{*} \mathrm{RS}$

with the value of $\mathrm{R}^{2}=0.48$ 
Influencing Factors Of Business-Fraud Intention On Young Muslim Entrepreneurs

In Palembang City

Febrianty $^{1}$, Divianto ${ }^{2}$

Based on the structural model can be explained that the IKB is influenced by ATTITUDE, SN, PBC, and RS. This means that the better ATTITUDE, SN, $\mathrm{PBC}$, and $\mathrm{RS}$ then the IKB will increase. The amount of influence of ATTITUDE to $\mathrm{IKB}$ is $0.40, \mathrm{SN}$ to $\mathrm{IKB}$ is equal to 0.02 , $\mathrm{PBC}$ to IKB is equal to 0.34 while $\mathrm{RS}$ to $\mathrm{IKB}$ is equal to 0.78 . This shows that $\mathrm{RS}$ has a larger influence than IKB compared with ATTITUDE, SN, and PBC.

\section{Figure 7.}

\section{Estimation Results of Full Model Based On Estimation}

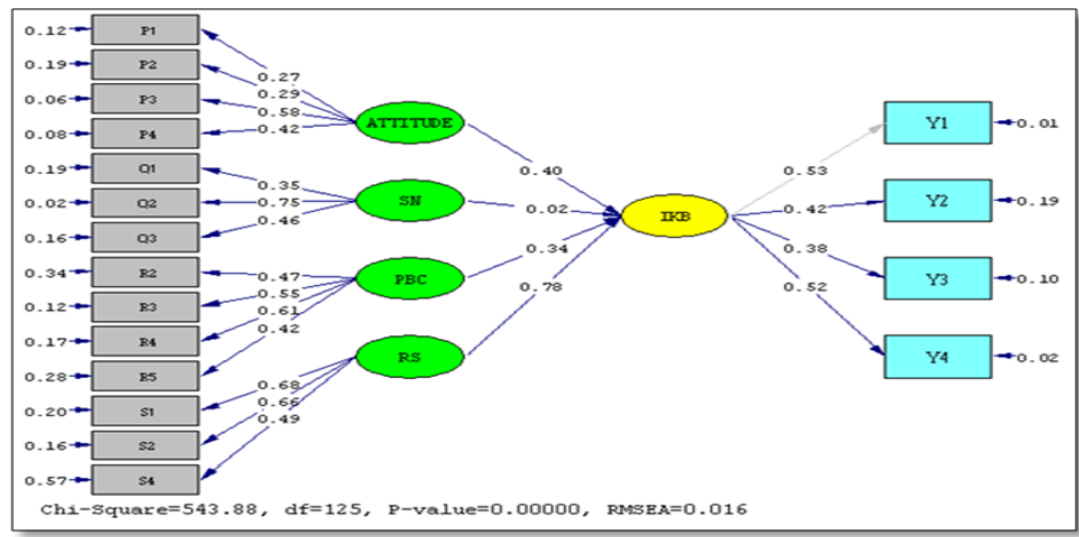

Loading value illustrates the correlation between research variables and their indicators. Thus the best indicator on a variable is the indicator which has the largest loading value because it indicates the higher correlation of these indicators with research variables.

\section{Structural Model Analysis}

Hypothesis test results presented in Table 7 as follows.

Table 7.

Conclusions of Hypothesis Test

\begin{tabular}{|c|c|c|c|c|c|c|c|}
\hline \multirow{2}{*}{$\frac{\text { No }}{\mathrm{I}}$} & Path & & $t$-value & Estimation & \multicolumn{3}{|c|}{ Information } \\
\hline & $\begin{array}{l}\text { ATTITUDE } \\
\text { IKB }\end{array}$ & $\rightarrow$ & $4, \mathrm{I} 3$ & 0.40 & $\begin{array}{l}\text { Positively } \\
\text { Influence }\end{array}$ & and & Significantly \\
\hline 2 & $\mathrm{SN} \rightarrow \mathrm{IKB}$ & & 0,23 & 0.02 & $\begin{array}{l}\text { Positively } \\
\text { Influence }\end{array}$ & and & Insignificantly \\
\hline 3 & $\mathrm{PBC} \rightarrow \mathrm{IKB}$ & & $\mathrm{I}, \mathrm{I} 4$ & 0.34 & $\begin{array}{l}\text { Positively } \\
\text { Influence }\end{array}$ & and & Insignificantly \\
\hline 4 & $\mathrm{RS} \rightarrow \mathrm{IKB}$ & & 2,62 & 0.78 & $\begin{array}{l}\text { Positively } \\
\text { Influence }\end{array}$ & and & Significantly \\
\hline
\end{tabular}




\section{DISCUSSIONS}

Hypothesis-I predicts a positive correlation between attitudes and intention of young Muslim entrepreneurs to commit business fraud. The result of hypothesis test shows hypothesis-I is accepted (Positively and Significantly Influence). Attitude toward behaviors is a predictor on the intention of young Muslim entrepreneurs to commit business fraud, it means that the intention of business fraud is supported by a person's attitudes toward business fraud behavior. The theory generally states that a person will have a positive attitude towards a behavior when it relates to positive goals and vice versa. However, this study found that the attitude of entrepreneurs on the intention to commit business fraud can be seen from the age and business orientation. Entrepreneurs with a young age and with a business performance oriented (bigger profits and business) more justify the business fraud action, when compared with dominant mastery entrepreneurs (level of creativity and proactive).

Hypothesis-2 predicts a positive correlation between subjective norms and intention of young Muslim entrepreneurs to commit business fraud. The result of hypothesis test shows hypothesis-2 is rejected (Positively and Inignificantly Influence). The reason for the rejection of hypothesis- 2 can be explained as follows. The theory generally states that a person will have positive subjective norm toward behaviors when it relates to positive goals and vice versa. However, in this study it was found that at a very young age and have become entrepreneurs then the subjective norm does not have relationship with the intention to commit business fraud. If the urge to take advantage of opportunities is quite large (in obtaining business profits) then the intention to commit business fraud will appear even not only to the intention but also in the form of business fraud acts or behavior.

Hypothesis-3 predicts a positive correlation between perceived behavioral control and intention of young Muslim entrepreneurs to commit business fraud. The result of hypothesis test shows hypothesis-3 is rejected (Positively and Inignificantly Influence). Perceived behavioral control toward behaviors is a predictor of young Muslim entrepreneur's intention to commit business fraud, it means that the intention to commit business fraud is supported by the control of one's behavior toward business fraud. The result shows that the high ability of a person to control oneself does not have relationship with the intention to commit business fraud.

Hypothesis- 4 predicts a positive correlation between role stress and intention of young Muslim entrepreneurs to commit business fraud. The result of hypothesis test shows hypothesis-I is accepted (Positively and Significantly Influence). Role 
stress toward behaviors is a predictor on the intention of young Muslim entrepreneurs to commit business fraud, it means that the intention of business fraud is supported by the role stress of a person on business fraud. The reason for accepting hypothesis 4 can be explained as follows. The theory generally states that a person will have a positive role stress on behaviors when it relates to positive goals and vice versa. The findings suggested that role stress influences business fraud intentions. Someone can have the intention of business fraud because of role conflict and role ambiguity which is furthermore said as role stress. The young entrepreneur finds the role conflict resulted from nonconformity to expectations. While the role ambiguity that comes from the work environment where the entrepreneur lacks sufficient information to develop and continue the business. Moreover, entrepreneurs who already have a business with a relatively young age between 18-25 years old and still in school or college, can be said the role stress will be more potential to occur. The role conflict has a negative impact on the behavior of individuals/entrepreneurs that can cause discomfort in their work and lower the motivation of work. Just like role conflict, role ambiguity can also cause the same thing because of inadequate information received by entrepreneurs in performing their role as entrepreneurs. In this condition, it can be said that young entrepreneurs are in an unstable condition and tend to make mistakes that require the help of the other party. The greater the conflict of perceived role stress, the higher the likelihood of business fraud intentions to be realized not only limited to intention but also in the form of acts or business fraud behavior.

Hypothesis-5 predicts that attitudes toward behavior, subjective norms, and perceived behavioral controls as well as role stress toward business fraud behavior have significant influence on the intention of young Muslim entrepreneurs to commit business fraud, with $\mathrm{R}^{2}$ value of 0.48 , it means that $48 \%$ of young Muslim entrepreneurs' intention to commit business fraud is influenced by attitudes toward behavior, subjective norms, and perceived behavioral control. While the rest $(52 \%)$ can be influenced by other factors. This shows that there are will still be potential intention to commit business fraud to Muslim young entrepreneurs who actually come from within internal themselves because they do not cling to the principles of Islam in a "kaffah" manner. The potential for intention to commit business fraud is due to the rationalization to justify this behavior.

\section{E. CONCLUSION}

The results of this study are: Hypothesis-I predicts a positive correlation between attitudes and intention of young Muslim entrepreneurs to commit 
business fraud (accepted). Hypothesis-2 predicts a positive correlation between subjective norms and intention of young Muslim entrepreneurs to commit business fraud (rejected). Hypothesis-3 predicts a positive correlation between perceived behavioral control and intention of young Muslim entrepreneurs to commit business fraud (rejected). Hypothesis-4 predicts a positive correlation between role stress and intention of young Muslim entrepreneurs to commit business fraud (accepted). Hypothesis-5 predicts that attitudes toward behavior, subjective norms, and perceived behavioral controls have significant influence on the intention of young Muslim entrepreneurs to commit business fraud, with $\mathrm{R}^{2}$ value of 0.48 , which means $48 \%$ of young Muslim entrepreneurs' intention to commit business fraud is influenced by attitudes toward behavior, subjective norms, and perceived behavioral control.

This study has limitations: it does not get a clear description of the type/specification of business fraud committed by young Muslim entrepreneurs. Therefore, further research is suggested to combine the spread of questionnaires with interviews so that the perceptions of respondents to existing statements can be known in depth. Another thing to add is some open-ended questions about the young entrepreneur's view of business fraud. This research also does not include other variables that are also suspected to have an effect on business fraud, namely: moral judgment, ethical climate, opportunity, rationalization, organizational factors, situational, individual, demography, etc.

\section{REFERENCES}

Ajzen, I. I99I. The theory of planned behavior. Organizational Behavior and Human Decision Processes, 50(2), I79-2II.

Ajzen, I. 2002. Constructing a TPB Questionnaire: Conceptual and Methodological Considerations., (Revised January 2006). Retrieved from http://www-unix.oit.umass.edu/aizen/pdf/tpb. measurement.pdf.

Ajzen, I. 2005. Attitudes, Personality, and Behaviour. New York: Open University Press.

Ajzen, I. 2007. Understanding Attitudes and Predicting Social Behavior. Englewood Cliffs, New Jersey: Prentice Hall.

Ajzen, I., and Fishbein. 1975. Belief, Attitude, Intentions and Behavior: an introduction to theory and research. California: Addison-Wesley. Publishing Company, Inc.

Anggelina, J., and Edwin, J. 20I4. Analisis Pengaruh Sikap, Subjective Norm dan 
Perceived Behavioral Control terhadapa Purchase Intention Pelanggan Sogo Department Store di Tunjungan Plaza Surabaya. Jurnal Strategi Pemasaran, 2(I), I-7.

Arifin, J. 2009. Etika Bisnis Islami. Semarang: Walisongo Press.

Azwar, S. I998. Sikap Manusia. Yogyakarta: Pustaka Pelajar.

Bobek, D. D., and R. C. Hatfield. 2003. An investigation of the Theory of Planned

Behavior and the role of moral obligation in tax compliance. Behavioural Research in Accounting, I5, I3-38.

Carpenter, T. D., and Reimers, J. L. 2005. Unethical and fraudulent financial reporting: Applying the theory of planned behavior. Journal of Business Ethics, 60(2), II5-I29. https://doi.org/I0.1007/sI055I-004-7370-9

Cressey, D. R. 1953. Other People's Money. New Jersey: Montclair, Patterson Smith.

Depag. 2013. Al-Qur'an Terjemah. Bogor: AlQur'an, Lajnah Pentashihan Mushaf.

Dubrin, A. J. 1982. Personnel And Human Resources Management. California: Kent Publising Company.

Ferdinand, A., T. 2005. Structural Equation Modelling. Semarang, Indonesia: Badan Penerbit Universitas Diponegoro.

Hall, J. 20I I. Sistem Informasi Akuntansi (4th ed.). Jakarta: Salemba Empat.

Hartono, J. 2007. Metodologi Penelitian Bisnis: Salah Kaprah dan PengalamanPengalaman (2007th ed.). Yogyakarta: BPFE.

Hays, R. T. 2005. The effectiveness of instructional games: a literature review and discussion. Naval Air Warfare Center Training Systems Division, I-63. https://doi.org/citeulike-article-id:3089090

Kahn, R. L., Wolfe, R. P., Quinn, J. D., and Snoek. I964. Organizational Stress: Studies in Role Conflict and Ambiguity. Oxford, England: John Wiley.

Kanuk, S. 2008. Perilaku Konsumen (7th ed.). Jakarta: Indeks.

Kartajaya, H., and Sula, M. S. 20I3. Syariah Marketing. Bandung: PT. Mizan Pustaka.

Katz, D., and Kahn, R. 1978. The Social Psychology of Organization (2nd ed.). New York: Wiley.

Kotler, P., and Amstrong, G. 2008. Dasar-dasar Pemasaran (9 Jilid I). Jakarta: PT. Indeks Kelompok Gramedia.

Kreitner, R., and Kinicki., A. 2005. PerilakuOrganisasi (Orgaizational Behavior). Jakarta: Salemba Empat.

Mujibatun, S. 20I2. Pengantar Fiqh Muamalah. Semarang: Lembaga Studi Sosial Dan Agama. 
IKONOMIKA

Volume 4, No I (2019)

Prabowo, H. Y. 2014. To be corrupt or not to be corrupt. Journal of Money Laundering Control, I7(3), 306-326. https://doi.org/IO.I I08/JMLC-I I2013-0045

Rebele, J. E., and Michaels, R. E. I990. Independent auditors' role stress: Antecedent, outcome, and moderating variabel. Behavioral Research in Accounting, 2, 124.

Said, S. 2002. Belajar dari Skandal Enron. Majalah Tempo, Kolom No. $49 / X X X / 4$ - IO Februari 2002. Retrieved from http://www.transparansi.or.id/2002/02/belajar-dari-skandal-enron/

Senatra, P. T. 1980. Role conflict, role ambiguity, and organizational climate in a public accounting firm. The Accounting Review, 4, 594-603.

Tang, T. L. P., and Chiu, R. K. 2003. Income, Money Ethic, PaySatisfaction, Commitment, and Unethical Behavior:Is the Love of Moneythe Root of Evil forHong Kong Employees? Journal of Business Ethics, 46(I), I3-30. https://doi.org/I0.I023/A:I02473I6II490

Uddin, N., and Gillett, P. R. 2002. The Effects of Moral and Self-Monitoring Intentions to Report on Financial Statements Reasoning on CFO Fraudulently. Journal of Business Ethics, 4O(I), I5-32.

Wolfe, D. T., and Hermanson, D. R. 2004. The Fraud Diamond: Considering the Four Elements of Fraud. CPA Journal, 74(12), 38-42. https://doi.org/DOI:

Zimmerer, W. T., and Scarborough., N. M. 2002. Pengantar Kewirausahaan Dan Manajemen Bisnis Kecil. Jakarta: PT. Rineka Cipta. 
Influencing Factors Of Business-Fraud Intention On Young Muslim Entrepreneurs In Palembang City

Febrianty $^{1}$, Divianto ${ }^{2}$

https://ejournal.radenintan.ac.id/index.php/ikonomika 